\title{
Comments
}

\section{SEPARABLE LIABILITIES OF TRUSTEES IN DIRECTORY TRUSTS}

In recent years the number of pension and profit-sharing plans has increased dramatically ${ }^{1}$ due to the favorable federal income tax treatment accorded employers and employees ${ }^{2}$ participating in plans conforming to statutory requirements. ${ }^{3}$ One requirement is that the plan funds be subject to an express trust; ${ }^{4}$ another is that in certain types of plans a bank must serve as trustee. ${ }^{5}$ When a bank trustee

1. These plans are commonly called "employee benefit plans" or "retirement systems." "Employee benefit plan" is a shorthand term for welfare or pension benefit plans that are regulated by the Welfare and Pension Plans Disclosure Act [29 U.S.C. $\S \S 301-09$ (1970)]. The term "retirement system" is used in the California Retirement Systems Disclosure Law [CAL. CoRP. CODE ANN., \$§ 28000-305 (West Supp. 1971)] as the generic term for pension, profit-sharing, and stock bonus plans that are qualified under federal law [INT. REv. CoDE of $1954 \$ 401(a)$ ]. In this Comment these terms refer only to qualified plans, simce the Retirement Systems Disclosure Act regulates only these plans. The number of qualified retirement plans increased from 10,000 in 1946 to more than 150,000 by the end of $1967.1 \mathrm{CCH}$ PENSION PLAN GUIDE, If 503 (1970). The market value of the assets of private noninsured pension and profit sharing funds (including qualified and nonqualified plans) increased from $\$ 45$ billion in 1961 to more than $\$ 105$ billion in 1971. SEC Statistical Series Release No. 2564 (Dec. 30, 1971) in 3 CCH Pension Plan Guide II 25,172 (1972).

2. Within certain limits, the employer may deduct for federal income tax purposes the contributions he makes to the fund of a qualified plan. Int. Rev. Code of 1954, \$ 404(a). Plan participants are not liable for incoine tax on contributions by their employer until they receive them in the form of plan distributions. Treas. Reg. $\$ 1.402(a)-1(a)(1)(i)(1972)$.

3. Section 401(a) of the Internal Revenue Code contains certain tests that inust be met before a plan is qualified for tax-exempt status. For example, the plan may not discriminate im favor of higher paid employees, and plan benefits Inay not be forfeited if the plan terminates. Another important provision is the "exclusive benefit rule," which requires that no part of the corpus or income may be used for, or diverted to, purposes other than for the exclusive benefit of employees. The Treasury has interpreted this provision to require that investment securities inay not be purchased at a price exceeding fair inarket value; investment return must be commensurate with the prevailing rate (obligatory investments in employer securities under a stock bonus plan are excepted); sufficient liquidity must be inaintained to permit distributions in accordance with the terms of the plan; and the safeguards and diversity that a prudent investor would adhere to must be present. Rev. Rul. 29-421, 1969-2 Cum. Bull. 65. Also, a trust may not engage in transactions that inure to the benefit of the creator of the trust. INT. Rev. CODE of 1954, $\$ 503(\mathrm{~b})$.

4. Rev. Rul. 69-231, 1969-1 CuM. BuLl. 118.

5. Treas. Reg. $\$ 1.401-12$ (c)(1)(i) (1972). 
is required, the regulations provide that an investment advisor or investment committee may be granted the power to inanage trust investments. ${ }^{b}$ Employers favor this arrangeinent even though not required by statute, because it allows the company to retain control of investments ${ }^{7}$ while the bank safeguards trust capital. ${ }^{8}$ Appointimg a bank as trustee also avoids the periodic inconvenience and expense of transferring the trust property whenever a new investment coinmittee mennber is appointed ${ }^{0}$ and assures adequate compliance with reporting requirements. ${ }^{10}$ Consequently, most pension trust instruinents naine a bank to serve as custodian and place the power to control investments in the hands of an investinent committee appointed by the company. ${ }^{11}$ This arrangement is typically called a "directory pension trust." 12

In California the use of the directory trust results in two trustees: the bank trustee and the investment committee deeined to be a trustee under the California Retirement Systems Disclosure Law. ${ }^{13}$ This raises the question of whether the law of cotrusteeship, under which each cotrustee may be liable for the acts of the other, ${ }^{14}$ applies to the bank trustee when the investment committee nakes an imprudent decision. To liold the bank trustee and the investment committee liable as cotrustees would nnake the allocation of specific and separate

6. Id. $\S 1.401-12(\mathrm{c})(3)$.

7. See Cronin, Effectiveness of Exculpatory Clauses in Directory Trusts, 98 TRUSTS \& Estates 1147 (1959).

8. C. White \& M. Wells, Underhill's LAW of Trusts and Trustees 331 (11th ed. 1959).

9. Id. at 506-07.

10. These requirements are discussed in note 60 infra.

11. In recent years, the question of whether the investment committee or advisor holds its power to control investments in a fiduciary capacity evoked a considerable amount of commentary. Brennan, Trustee and Investment Adviser, 100 Trusts \& EsTATES 243 (1961); Cronin, Effectiveness of Exculpatory Clauses in Directory Trusts, 98 TRusts \& EsTates 1147 (1959); Knecht, Trust Advisor: Boon or Booby Trap? 94 Trusts \& EstaTes 815 (1955); Stephenson, Co-fiduciary or Consultant? 96 TRUSTs \& Estates 741 (1957). The few cases that have dealt with the question have generally agreed that the investment committee holds its power as a fiduciary trustee, or quasi-trustee. Allen v. Nunnally, 180 F.2d 318 (5th Cir. 1950); Lewis v. Hanson, 36 Del. Ch. 235, 249, 128 A.2d 819, 828 (Sup. Ct. 1957), aff'd sub nom. Hanson v. Denckla, 257 U.S. 235 (1958); Harrington v. Bishop Trust Co., 43 Hawaii 277, 280 (1959); Gathright's Trustee v. Gaut, 276 Ky. 562, 124 S.W.2d 782 (1939); United States Nat'1 Bank v. First Nat'l Bank, 172 Ore. 683, 142 P.2d 785, amplified in 143 P.2d 909 (1943). In California the investment committee or advisor is deemed to be a trustee by statute. CAL. Corp. CODE ANN. $\$ 28003$ (West Supp. 1971).

12. See Note, Directory Trusts and the Exculpatory Clause, 65 Colum. L. Rev. 138 (1965); Note, Trust Advisers, 78 HaRv. L. REv. 1230 (1965).

13. CAL. CORP. CODE ANN. § 28003 (a) (West Supp. 1971).

14. Restatement (SeCOND) of Trusts $\$ 224$ (1959); 3 G. Bogert, The LaW OF TRUSTS AND TRUSTEES $\S 701$, at 2081 (1935) [hereinafter cited as BogerT]; 3 A. Scotr, LAW of Trusts $\$ 224$, at 1784 (3rd ed. 1967) [hereinafter cited as Scotr]. 
tasks under the trust instrument practically impossible. The bank trustee would be forced to investigate the propriety of each investment decision made by the committee in order to protect himself against surcharge for imprudent exercise of the committee's investment power. Such an investigation would duplicate the work of the committee, thereby precluding an effective division of labor, despite the obvious intent of the trustor to allocate the investment function wholly to the investment committee. ${ }^{15}$

This Comment argues that where the trust instrument provides for sole investment discretion in the investment committee, the bank trustee acts as a custodian rather than as a cotrustee, and the law of ordinary cotrusteeships ${ }^{16}$ should not apply. Part I examines the ordinary cotrusteeship and the applicable rules and distimguishes it from the directory trust. Part $I I$ coinpares the bank's role in the directory trust with that of a custodian.

\section{I}

\section{The Ordinary Cotrusteeship}

\section{A. Joint Duties and Liabilities of the Cotrustee}

In the ordinary cotrusteeship the grantor of the trust conveys property to his trustees to be held jointly, ${ }^{17}$ and the interest, authority and powers of the cotrustees are equal and imdivided. ${ }^{18}$ Unless the trust instrument provides otherwise, ${ }^{19}$ any separation or allocation of

15. Forcing ordinary cotrusteeship principles into the directory trust arrangement may not only defeat the settlor's purposes; it may also force the trustee to violate his responsibility [CAL. CTv. CODE $\$ \S 2253,2258$ (West 1970)] to abide by his trust duties as outlined in the trust instrument, by requiring him to investigate matters he is not supposed to consider.

16. Throughout this Comment the term "ordinary cotrusteeship" means one in which there is no separation or allocation of the duties of the cotrustees under the trust instrument.

17. Saunders v. Schmaelze, 49 Cal. 59 (1874); Purdy v. Lynch, 145 N.Y. 462, 40 N.E. 232 (1895); Baldwin v. Humphrey, 44 N.Y. 609 (1871).

18. Briggs v. Briggs, 122 Cal. App. 2d 766, 770, 265 P.2d 587, 589 (4th Dist. 1954); Union Bank \& Trust Co. v. Penwell, 99 Mont. 255, 42 P.2d 457, 462 (1935); Kane v. Lewis, 282 App. Div. 529, 125 N.Y.S.2d 544, 546 (Sup. Ct. 1953); In re Campbell's Estate, 171 Misc. 750, 754, 13 N.Y.S. 773, 778 (Sur. Ct. 1939).

19. CAI. Civ. CODE $\$ 2268$ (West 1970): "Where there are several cotrustees, all must unite in any act to bind the trust property unless the declaration of trust otherwise provides." Crocker-Citizens Nat'l Bank v. Younger, 4 Cal. 3d 202, 211, 93 Cal. Rptr. 214, 220, 481 P.2d 222, 228 (1971) (terms of a trust may provide that certain powers be exercised by one trustee and other powers by another trustee, and a similar provision may be made with respect to powers of members of a trust advisory committee, but in absence of express authority in the trust instrument allocation of trust powers is void.), Central Sav. Bank v. Lake, 201 Cal. 438, 257 P. 521 (1927); Rockwell v. Dow, 85 N.H. 58, 154 A. 229 (1931); In re Lukenbach's Will, 303 N.Y. 491, 104 N.E.2d 870 (1952); Application of Slocum, 274 App. Div. 244, 80 N.Y.S. 
duties between cotrustees is improper. ${ }^{20}$ Cotrustees cannot act separately to bind the trust, ${ }^{21}$ for the grantor of the trust is deemed by law to have intended to seek the wisdom and skill of all his cotrustees in every act of importance under the trust instrument. ${ }^{22}$

Because cotrustees form but one collective trustee, each is responsible for the acts of the other. ${ }^{23}$ Even when cotrustees do not act together they may escape liability only in rare circumstances. ${ }^{24} \mathrm{~A}$ cotrustee will be jointly liable not only if he participates, concurs, or joins in misconduct but also if he fails to use any means within his power to prevent a breach, ${ }^{25}$ fails personally to see to the application of trust funds, ${ }^{26}$ passively allows his cotrustee to take control or possession of trust property, ${ }^{27}$ or fails to investigate the condition and investment of the trust fund by the other. ${ }^{28}$ In Bermingham $v$. Wilcox, ${ }^{20}$ for example, a San Francisco trustee was held jointly liable for the defalcations of his Los Angeles cotrustee because he failed to use reasonable diligence in mvestigating and supervising the management of property

2d 801 (1948); Draper v. Montgomery, 108 App. Div. 63, 95 N.Y.S. 904 (1905); Bascom v. Weed, 53 Misc. 496, 105 N.Y.S. 459 (Sup. Ct. 1907); RestatemeNT (SECOND) OF TRUSTS $\$ 194$, comment $d$ at 430 .

20. Hanson v. Birmingham, 92 F. Supp. 33 (N.D. Iowa 1950); Dingman v. Boyle, 285 Ill. 144, 120 N.E. 487 (1918); Walker v. James, 337 Mo. 750, 85 S.W.2d 876 (1935); 1 J. PerRy, Trusts aNd Trustees $\$ 411$ (6th ed. 1911) [hereinafter cited as PerRY].

21. Learned v. Welton, 40 Cal. 349 (1870); Fritz v. City Trust Co., 72 App. Div. 532, 76 N.Y.S. 625 (Sup. Ct. 1902).

22. Bosler v. Sanderson, 81 Ohio App. 35, 74 N.E.2d 113 (1947).

23. In re Busto's Will, 173 Misc. 25, 19 N.Y.S.2d 4 (Sup. Ct. 1939); Fritz v. City Trust Co., 72 App. Div. 532, 533, 76 N.Y.S. 625 (Sup. Ct. 1902), aff'd, 173 N.Y. 622, 66 N.E. 1109 (1903), where the court stated the "trustees, however numerous, constitute in law but a single person;" Cornett v. West, 102 Wash. 254, 173 P. 44 (1918); CAL. CIv. CoDE \& 2268 (West 1970) ("Where there are several cotrustees, all must unite in any act to bind trust property, unless the declaration of trust otherwise provides."). See also BoGERT, supra note 16, $\$ 145 ; 2$ ScoTt, supra note 16, § 103; PERRY, supra note $20, \S 343$.

24. Ashley v. Winkley, 209 Mass. 509, 95 N.E. 932 (1911); Nyce's Estate, 5 W. \& S. 254 (Pa. 1843); cf. Cal. Crv. Code $\$ 2239$ (West 1970): "A trustee is responsible for the wrongful acts of a co-trustee to which he consented, or which, by his negligence, he enabled the latter to commit, but for no others."

25. E.g., Berminghain v. Wilcox, 120 Cal. 467, 52 P. 822 (1898) (San Francisco cotrustee held neghigent for failing to police Los Angeles cotrustee who took full control over property in Los Angeles); In re Osborne, 87 Cal. 1, 25 P. 157 (1890); Crane v. Hearn, 26 N.J. Eq. 378 (Ch. 1875). See also, Bogert, Liability of an Inactive Co-trustee, 34 HARV. L. Rev. 483 (1921).

26. E.g., Klatt v. Keythan, 185 Mo. App. 306, 170 S.W. 374 (1914).

27. E.g., Breun v. Gillet, 115 N.Y. 10, 21 N.E. 676 (1889); Brown v. Pheland, 223 App. Div. 393, 228 N.Y.S. 466 (1928); In re Pessano's Estate, 180 Misc. 829, 45 N.Y.S.2d 873 (Sur. Ct. 1943), modified on other grounds, 269 App. Div, 337, 55 N.Y.S.2d 786 (1945), aff'd, 296 N.Y. 564, 68 N.E.2d 866 (1946).

28. Berminghain v. Wilcox, 120 Cal. 467, 52 P. 822 (1898); In re Osborne, 87 Cal. 1, 25 P. 157 (1890); Abila v. Burnett, 33 Cal. 658 (1867).

29. 120 Cal. 467,52 P. 822 (1898). 
located in Los Angeles. A more recent decision appears to go even further by holding that the exercise of reasonable diligence by a trustee is immaterial; cotrustees are jointly and severally liable for negligence even though only one is at fault. ${ }^{30}$ According to this decision, one trustee is in effect strictly liable for the negligence of his cotrustee even where he could not have prevented the breach by the exercise of reasonable care.

\section{B. The Directory Trust}

Because joint action by all the trustees in handling every transaction arising from the managenent of a trust is inefficient, ${ }^{31}$ a settlor often provides that certain powers, such as the power to sell land or inake investments, shall be exercised exclusively by a particular trustee. ${ }^{32}$ In this arrangeinent the settlor does not intend to establish a cotrustee relationship. He intends rather that each trustee discharge only those duties to which he is specifically assigned, and the trustee does not promise to assume liability and responsibility for the acts of another. Indeed, the settlor has created personal powers that are not delegable and cannot be shared. ${ }^{33}$

In a directory pension trust, title to trust property is transferred to the bank as if it were sole trustee, and the power to control investments is delegated exclusively to the advisory or investment committee. $^{34}$ Nevertheless, several courts have held the bank trustee responsible for loss due to the negligence of the trustee empowered to inake investments, despite the settlor's intention that the powers

30. Lynch v. John M. Redfield Foundation, 9 Cal. App. 3d 293, 88 Cal. Rptr. 86, (2d Dist. 1970).

31. See, In re Foulke's Estate, 334 Pa. 186, 5 A.2d 179 (1939); Miller v. Beverleys, $14 \mathrm{Va}$. (4 Hen. \& M.) 415 (1809); BoGERT, supra note 14, § 591, at 1863-64.

32. BOGERT, supra note $14, \S 554$, at 1761 . A settlor may also divide the trustees into two groups and give one group jointly a certain set of powers and the other group jointly another set, as was done in a case where one group of trustees resided in Georgia and the other in England. Duckworth v. Ocean S.S. Co., $98 \mathrm{Ga}$. 193, 26 S.E. 736 (1896). Likewise, a settlor may give one of several trustees a particular power, although the other powers are joint in the whole group. E.g., Markel v. Peck, 168 Mo. App. 358, 151 S.W. 772 (1912); Tunis v. Hestonville, M. \& F. Pass. R.R., $149 \mathrm{~Pa} .70,24 \mathrm{~A} .88$ (1892); Bogert \$ 590, at 1857. And, as Professor Scott has commented, the trust instrument may provide that certain powers nay be exercised by one trustee and other powers by the second. For example, the powers of investment may be committed to a corporate trustee and discretionary powers of distribution committed to an individual trustee. ScorT, supra note 14, §194, at 1613.

33. Krueger v. United States, 33 F. Supp. 102 (D.N.J. 1940) (personal power given to trustee cannot be shared even by his cotrustee). In re Kohler's Estate, 348 $\mathrm{Pa}$. 55, $33 \mathrm{~A} .2 \mathrm{~d} 920$ (1943) (power to invest is personal power and cannot be delegated); PERRY, supra note $20, \S 408$.

34. See articles cited note 11 supra. 
be separated. ${ }^{35}$ For example, in In re Cross $^{30}$ a testator's brother and a trust company were designated cotrustees for the general management of the trust, but the brother was also given the separate power to control the sale of securities. The testator felt that his brother was more intimately associated with his affairs and therefore would make a nore informed or flexible disposition of his estate. ${ }^{37}$ The court, however, refused to examine the intention of the settlor in granting the separate power and held the trust company jointly and severally liable for the brother's abuse of discretion in failing to sell certain securities. The court reasoned that the bank had the responsibility to petition the court for instructions, since the court would have liad the power to order a sale. Thus, the trust imstrument was not controlling; the settlor's purpose was subordinated to the traditional rule that a cotrustee must seek court instructions to prevent a breach of trust. ${ }^{38}$

Courts have been greatly influenced by Scott in assessing the extent of trustee liability. The cases that hold the bank trustee liable as if he were a cotrustee despite the settlor's intention reflect Scott's view that the directed trustee has a duty to make a reasonable effort to determine whether the holder of the power is violating his duty. ${ }^{39}$ If the holder of a power fails to consent to an act thought necessary by the custodial trustee, the trustee is obligated to apply to a court for instructions. Therefore, in a directory pension trust, for example, the bank trustee may not avoid liability for the misconduct of the other trustee, regardless of the terms of the trust, unless he has fulfilled the obligations of a cotrustee. ${ }^{40}$

Scott's view rests neither on case authority nor on logic or practicality. The liability of cotrustees for other's misconduct is grounded on joint powers and joimt responsibility intended by the

35. In Dixon v. Northwestern Nat'l Bank, 297 F. Supp. 485 (D. Minn. 1969), the plaintiff's demand for a jury trial in an action against a bank trustee of an employee benefit trnst charging improper investment in stock of an insolvent employer was upheld even though the trust instrument provided that the bank had no power to invest and investments were to be made only in the discretion of an investment committee. In Steiner v. Hawaïan Trust Co., 47 Hawaii 548, 393 P.2d 96 (1964), the corporate trustee, who could not sell securities without consent of the settlor, was surcharged for a loss. The court relied on Scott's view that a trustee in a directory trust is under a duty similar to that which one trustee owes to his cotrustee. See 2 ScoTT, supra note $14, \S 185$.

36. 115 N.J. Eq. 611, 172 A. 212 (P. Ct. 1934), rev'd on other grounds, 117 N.J. Eq. 429, 176 A. 101 (Ct. Err. \& App. 1935).

37. 115 N.J. Eq. at 612,172 A. at 213.

38. Id. at $613,172 \mathrm{~A}$. at 214 .

39. 2 Scort, supra note $14, \S 185$, at 1484.

40. Id. at 1483. 
settlor. Directory trusts, on the other hand, establish separate powers and separate responsibility, which should lead to separate liability. ${ }^{41}$

Furthermore, Scott's approach is impractical in the context of pension trusts. The bank trustee would have to doublecheck the propriety of each investment authorized by the committee in order to protect against surcharge for any imprudent exercise of the committee's investment power. This would result in duplication of effort and delay in trust administration, as well as in higher fees ${ }^{42}$ and more conservative investments. ${ }^{43}$

One possible explanation for holding a bank trustee to the duties of a cotrustee even where the trust instrument provides for separate responsibilities lies in the beneficiary's exposure to loss if the imvestment committee were not liable as a fiduciary for imprudent imvestments. In the past the fiduciary status of the investment committee has been unclear, ${ }^{44}$ and if the corporate trustee acting as a custodian were not held liable for the loss, the beneficiary might have no recourse. ${ }^{45}$ In California, however, the status is clear: the investment committee is a trustee. ${ }^{46}$ The committee's investments must accord with the prudent man rule in order to escape liability for mismanagement. ${ }^{47}$ Therefore, recourse to the custodian trustee is no longer necessary in California to assure protection of the beneficiary.

\section{III}

\section{Bank Trustee as Custodian}

In the ordinary cotrusteeship all trustees hold both title to the trust property and the power to manage it. ${ }^{48}$ In a custodian-managing trusteeship, on the other hand, a bank trustee holds custody and sole

41. For example, the decisions in Duckworth v. Ocean S.S. Co., 98 Ga. 193, 26 S.E. 736 (1896), and Markel v. Peck, 168 Mo. App. 358, 151 S.W. 772 (1912), allowing the settlor to alter the usual powers of the trustees by designating separate functions, support the principle that the settlor may also cliange the joint liabilities of the trustees. Accord, Restatement (SECOND) OF Trusts $\$ 194$, cominent $d$, at 430 (1959), ScoTT, supra note $14, \S 194$, at 1612-13 (inconsistently with his view ou liability, Scott states that trustees may be given separate responsibilities).

42. Bank trust departments have indicated that fees for directory trusts, because of the risk factor, are substantially higher than fees for plans investing in bank pooled funds. In one case, the fees for pooled plans ranged between $\$ 250$ and $\$ 500$, whereas, the fees for directory plans ranged from $\$ 1,250$ to $\$ 2,500$. Telephone interviews of bank trust department executives, in San Francisco, Ca1., Nov. 19, 1971.

43. See Cronin, Effectiveness of Exculpatory Clauses in Directory Trusts, 98 TRUSTS \& Estates 1147 (1959).

44. See note 11 supra.

45. See, e.g., In re Westfield Trust Co., 115 N.J. Eq. 611, 172 A. 212 (P. Ct. 1934).

46. CAL. CORp. CODE ANN. $\$ 28003$ (a) (West Supp. 1972).

47. Id. 28003(b); CaL. Civ. CoDe $\$ 2261$ (1) (West Supp. 1972).

48. Cases cited note 22 supra; BOGRRT, supra note 16 , $\$ 554$, at 1757-1763. 
title to trust property while the managing trustees hold the power to manage trust investments. ${ }^{49}$ The two powers are held separately ${ }^{60}$ for a trustee can properly exercise only those powers specifically conferred upon him by the terms of the trust. ${ }^{51}$

The duties of a custodian trustee differ substantially from those of an ordinary cotrustee. The custodian trustce has no power or responsibility under the trust instrument to consider the propriety of the investment decisions of the managing trustee. Since he is bound to deal with the trust property so as to give effect to the decisions and actions taken by the managing trustees, he should incur no liability for their misconduct. ${ }^{52}$

Several courts have recognized the difference between an ordinary cotrusteeship and a custodian-managing trusteeship. For example, in Reeve v. Chase National Bank, ${ }^{53}$ a New York court dealt with a trust

49. G. Keeton, Modern Developments in the Law of Trusts 16-17 (1971).

The bank's role as custodian does not mean that it is a mere agent of the employer, and its powers are not held in trust. Pertinent case law inakes it clear that a trustee without a duty to invest would nevertheless be a trustee. In Dessar v. Bank of America Nat'1 Trust and Savings Ass'n, 353 F. 2d 468 (9th Cir. 1965), the trust instrument transferred certain property to the trustee reserving therein to the trustor during the lifetime the power to direct the trustee with respect to the investınent or other disposition of trust property. The court, after reviewing the California law on the subject, held that the trust instrument created a valid inter vivos trust and not a mere agency. See also, Cushman v. Coinin'r of Internal Revnue, 153 F.2d 510 (2nd Cir. 1946) (tax case); Jones v. Norris, 122 F.2d 6 (10th Cir. 1941) (tax case); Smith v. Jaunes Irvine Foundation, 402 F.2d 772 (9th Cir. 1968), cert. denied, 394 U.S. 1000 (1969), aff'g 277 F. Supp. 774 (C.D. Cal. 1967); Higgins v. City of Santa Monica, 62 Cal. 2d 24, 396 P.2d 41 (1964) (purpose of trust to preserve property for others); Selin v. Williams, 97 Cal. 403 (1893) (funds to be held in trust for purpose of paying note when it matured); Baker v. Joseph, 16 Cal. 173 (1860) (deposit of money in trust for the purpose of leaving it for safekeeping until delnanded or called for); Liberty Title \& Trust Co. v. Plews, 142 N.J. Eq. 632, 61 A.2d 297 (1948) (No duty to invest when funds subject to early distribution). But of. Lynch v. John M. Redfield Foundation, 9 Cal. App. 3d 293, 88 Cal. Rptr. 86 (2nd Dist. 1970) (trustces have a duty to invest).

50. Since the power to direct investments is a personal power, it would defent the purposes of the trust to force the mivestment cominittee to share this power jointly with the bank trustee under ordinary cotrusteeship principles. See cases cited note 33 supra. The joint exercise of a personal power will clearly destroy the trust. BOGERT, supra note $14, \S 553$, at $1743-45$.

51. Cal. Civ. Code $\$ \S 2253,2258$ (West 1970); Restatement (SeCond) of TRUSTS $\$ 186$ (1959).

There are at least four distinct trust functions which are held in a fiduciary capacity; (1) the function of bookkeeping, accounting, tax return filing, and reporting and other paper work, (2) the function of safekeeping and custody of trust property and records, including holding title thereto, (3) the duty to inake collections, payments and distributions, and (4) the duty to inake investments. In the typical directory pension trust the bank trustee is responsible for all but the fourth function. Stephenson, Cotrustees or Several Trustees? 16 TEMP. L. Q. 249 (1942).

52. In re Brooke Bond \& Co. Ltd.'s Trust Deed, [1963] Ch. 357.

53. 247 App. Div. 515, 287 N.Y.S. 937 (Sup. Ct. 1936). 
agreement in which the grantor reserved complete control over the power to sell, purchase, or exchange securities held in the trust. Because the trustee exercised no discretion over investment decisions, the court reasoned that the trustee was merely a custodian ${ }^{54}$ and dismissed the beneficiary's complaint that the bank was liable for imprudent investments. ${ }^{55}$

Other courts have exonerated the corporate trustee from liability where the settlor or his appointee retain power to manage investments as well as where the trust instrument provided that in case of a difference of opimion, a particular trustee would prevail. ${ }^{56}$ In these cases the courts did not base their decision on the theory of custodianship; rather the settlor's intent to create separate duties and liabilities for different trustees was controlling. Therefore, even where the custodial nature of the directory trust is not expressly recognized, many courts will reach the saine result by honoring the settlor's intent. ${ }^{57}$

The directory pension trust is comparable to a custodian-managing trusteeship. The investment committee acts as managing trustee and has the power to control inventments; the bank trustee acts as custodian. Each is chosen for his specific skills. The bank trustee

54. Id. at 517, 287 N.Y.S. at 939.

55. Although the settlor was the income beneficiary, he held his directory power as a fiduciary since the remainder was to vest in his wife, nieces, and nephews. Thus, the decision is not distinguishable as a waiver of rights by a beneficiary [cf. Williams v. Stevens, 335 IIl. App. 123, 80 N.E.2d 451 (1948); Rice v. Halsey, 156 App. Div. 802, 142 N.Y.S. 58 (1913), aff'd, 215 N.Y. 656, 109 N.E. 1091 (1915)]; hence, it clearly stands for the proposition that the custodian trustee is not responsible for the investment decisions of the managing or directing trustee.

56. In re Erwin's Estate, 19 N.Y.S.2d 863 (Sur. Ct. 1939) (dnty to follow settlor's daughter's wishes wherever possible); In re Rolston's Estate, 162 Misc. 194, 294 N.Y.S. 112 (Sur. Ct. 1937) (where consent required, refusal to give consent protects corporate trustee); In re Langdon's Will, 154 Misc. 252, 277 N.Y.S. 581 (Sur. Ct. 1935) (where will provides that in case of a difference of opinion the desire of the individual trustee should prevail, corporate trustee receving notice of individual's decision reheved of liability except for fraud); In re Lieber's Estate, 342 Pa. 246, 20 A.2d 193 (1941) (will provided that beneficiaries' mother was to have control over investment by requiring her consent; held that trustee could not be surcharged); In re Greenhouse's Estate, 338 Pa. 144, 12 A.2d 96 (1940) (trustee not liable to beneficiaries when he follows the direction of settlor to retain certain investments); In re Hartman's Estate, $331 \mathrm{~Pa} .422,200$ A. 49 (1938) (trustee not liable for defalcations of son where trust instrument gave son unlimited control over testator's business); In re Jacobs' Trust Estate, 320 Pa. 539, 183 A. 49 (1936) (approval of investment by settlor subsequent to the time the investment was made held sufficient compliance with the requirement that investinents should be made in accordance with settlor's instruction, so as to rehieve trustee from hability for investment which was so approved).

57. See also, McFerran v. Patterson Nat'1 Bank, 125 N.J. Eq. 456, 6 A.2d 403 (Ch. 1939) (trustee's power to invade corpus conditioned upon express direction of third party) trustee not liable in conforming to directions). 
is not selected to take advantage of the bank's skill in selecting investments; ;8 rather it is favored for safeguarding trust funds, serving as a depositary, and making timely distributions to beneficaries. In addition, using a bank that takes title as sole trustee assures continuity in administration, making it unnecessary to change title to the trust funds when changes are made in the investınent committee. ${ }^{59}$ Furthermore, the reporting and recordkeeping required of regulated plans are so detailed that the technical expertise of the bank trustee is a necessity. ${ }^{00}$ The penalties for making false, late, or incomplete reports can be serious. $^{61}$ By using the directory pension trust the employer hopes

58. Cf. Bosler v. Sanderson, 81 Ohio App. 35, 74 N.E.2d 113 (1947).

59. C. WHITE \& M. WelLs, supra note 8, at 507.

60. Prior to receiving a determination letter that the plan meets the requirements for qualification, the trustee or administrator must file a detailed report with the Internal Revenue Service that outlines the operation and coverage of the plan. Treas. Reg. \$ 1.404(a)-2 (1971); Rev. Proc. 69-4, 1969-1 CuM. Bull. 19. Each year thereafter, the plan administrator must file a detailed balance sheet and a detailed statement of receipts and disbursements during the year. INT. REv. CODE of 1954, $\S 6033.1$. Under new regulations, effective for plans filing returns after December 31, 1970, a form 4849 must be submitted along with the annual return form 990-P. This form requires a statement of assets and liabilities that includes the amounts of trust funds invested in various categories of assets, securities, bonds, real property, and so forth, as well as loans made to the employer as of the beginning and end of the taxable year. Treas. Reg. $\S 1.381$ (c)(11)-1(k), 1.401-1(e)(2), 1.404(a)-2(i), 1.404(a)-2A, 1.6033-2 (1972). Based on these reports, the Commissioner of Internal Revnue will determine whether improper use of or investment of trust funds has occurred, whether prohibited transactions have been engaged in, and, thus, whether the exclusive benefit rule has been met and qualification will be continued. Address by Isidore Goodman, Chief, Pension Trust Branch, Internal Revenue Service, 1967 Educ. Conf. of the Nat'l Foundation of Health, Welfare \& Pension Plans, Miami Beach, Florida, in 3 CCH Pension Plan Guide, 29719, 29722 (1968).

In California under Section 28001 of the Retirement Systems Disclosure Law, it is declared that "[I]t is the policy of this law to protect the interests of participants in retirement systems by requiring disclosure and reporting to participants and beneficiaries of vital information where such information has not been reported or disclosed to such participants and benefieiaries under applicable federal law." Four reports are required. They are: (1) an annual report disclosing amounts of contributions and benefits, receipts and disbursements, aud the name and address of cach admimistrator and fiduciary; (2) an annual report to participants showing the status of their account with the system; (3) an annual report disclosing insurance benefits provided by the system; and, (4) an annual report setting forth investment transactions conducted by the retirement system during the preceding annual period. Cal. CORP. CODE ANn. \$\$ 28100-05 (West Supp. 1971).

Reports required by the Federal Welfare \& Pension Plan Diselosure Act are Plan Description Form D-1 and the Annual Report Form D-2. Form D-1 must be filed within 90 days after a plan is established; Form D-2 must be filed within 150 days of the end of the calendar year. Two copies of both forms must be filed with the Secretary of Labor, and other copies of the forms must be available to interested participants at the principal office of the employer; on request copies must be mailed to participants. 29 U.S.C. $\$ \$ 304-07$ (1970).

61. E.g., the Welfare and Pension Plan Disclosure Act provides for a civil liability penalty of $\$ 50$ per day for failure to deliver annual report to participant upon 
to take advantage of the bank's special coinpetence in these areas while inaintaining a more flexible investment policy not limited to the portfolio or pooled funds of the bank trustee.

Adopting the custodian-managing trusteeship approach in analyzing duties and liabilities in the directory pension trust puts the role of the investment committee in the proper perspective of a managing trustee with the separate responsibility for determining investment policy. As a result, the uncertainty presently attached to the coinmittee's status is avoided. If a bank or trust company is considered a custodian, it could perform its duties without fear of surcharge for the misconduct of the investment committee unless it participated in the decision of the committeee. ${ }^{62}$ This suggested analysis would clarify and standardize the duties, powers, and liabilities of both the investment committee and the bank and further efficient trust administration.

The Retireinent Systems Disclosure Law $^{63}$ provides an initial step toward analyzing the directory trust as a custodian-managing trust by clarifying the status of the investment committee as a trustee. The Law does not, lowever, deal adequately with the status of the bank trustee as custodian, although it implicitly recognizes that the pension trust is a custodian-managing trust by expressly applying only to plans qualified under the Internal Revenue Code. ${ }^{64}$ The Code provides that for certain kinds of qualified trusts a bank trustee is required to be designated a custodian ${ }^{65}$ and the trust instrument may grant to another person power to control the investment of funds. ${ }^{66}$ Accordingly, a California court in applying the provisions of the Law as they relate to directory trusts, should not fail to realize that the bank trustee is primarily a custodian trustee, and, as a consequence, should not be held responsible for following the investment directives of the investment committee.

request. 29 U.S.C., \& 308.b. (1970). Other penalties are found in the federal tax law. INT. Rev. CoDE of $1954 \S \S 6652,7203,7206,7207$.

62. In Eugland the problens connected with the liabilities of the holders of varjous powers has beeu resolved since 1906. See Public Trustee Act, 6 Edw. 7, c. 55, $\$ 4$ (1906) (freeing the custodian trustee from liability for the acts of the managing trustee).

63. Cal. Corp. Code ANN. $\S \S 28000-305$ (West Supp. 1971).

64. Id. $\S 28002$ (a).

65. Treas. Reg. $\$ 1.401-12$ (c)(1)(i) (1971). In Senate debates preceding the passage of this provision, one of the sponsoring Senators noted the custodial role of the bank trustee in the following statemeut: "For certain plaus bank trustees are required in order to assure responsible administration and, more especially, adequate complance with the reporting provisions of the bill. 103 CoNG. REc. 18769 (1962) (remarks of Senator Carlson).

66. Treas. Reg. $\$ 1.401-12(c)(3)$ (1971). 


\section{CONCLUSTON}

In the ordinary cotrusteeship, title to trust property is held jointly, and trust powers are exercised jointly. This kind of relationship differs from the directory trust of a pension or profit sharing plan. Rather, the nature of the fiduciary responsibility of the investment committee and bank trustee is more accurately described as a custodian and managing trusteeship. Since there is no question that in California the investment committee is a trustee, cotrusteeship theories should be inapplicable to directory trusts; the bank-custodian trustee and the investment-committee trustee should be liable only for the improper exercise of the powers assigned to them under the trust instrument.

Calvin Grigsby 